\title{
Career Adaptability in the 9th Year: Efficacy of an Intervention in Two Consecutive School Years
}

\author{
Catarina Luzia de Carvalho ${ }^{1}$ \\ Maria do Céu Taveira ${ }^{1}$ \\ Rodolfo Augusto Matteo Ambiel ${ }^{2}$
}

\begin{abstract}
The program Eu Pertenço ao Meu Futuro! (I Belong to My Future!) has evidence of effectiveness in the career adaptability of 9th-year Portuguese students. This study evaluates its effectiveness in two consecutive school years, 2015/16 and 2016/17 a period with a series of government changes that impacted school educational projects. This study was conducted with 2,376 students $(1201(50.5 \%)$ boys; age $M=14.53$ years; $S D=.836), 1138$ of whom were randomized into the experimental group and 816 in the control group. Data were collected by means of the Adaptability Scale, administered in a pre- and posttest with a sevenweeks interval, and treated using the MANOVA. The intervention achieved the expected results regarding confidence and control in 2016/17. The program had different effects in the two school years, reaching more favorable outcomes in the second year, which may be explained by contextual factors and the intervention process.
\end{abstract}

Keywords: adaptability, psychological intervention, adolescence, environmental effects

\section{Adaptabilidade de Carreira no $9^{\circ}$ ano: Eficácia da Intervenção em Dois Anos Letivos Consecutivos}

Resumo: O programa Eu Pertenço ao Meu Futuro! tem evidências de eficácia na adaptabilidade de carreira de alunos/as portugueses do 9. ${ }^{\circ}$ ano escolar. Contudo, variações desta eficácia, nunca foram analisadas. Este estudo teve por objetivo avaliar a eficácia daquele em dois anos letivos consecutivos, 2015/16 e 2016/17, período de mudanças governamentais, com impacto nos projetos educativos das escolas. Participaram 2376 alunos/as [1201 (50.5\%) rapazes; idade $M=14.53$ anos; $D P=.836$ ], 1138 do grupo experimental e 816 do grupo de controlo. Respostas à Escala sobre Adaptabilidade, num pré e pós-teste, intervalados sete semanas, foram tratadas por meio da MANOVA. Os resultados indicam que a intervenção atingiu resultados esperados, na confiança e no controlo, em 2016/17. O programa teve efeitos distintos nos dois anos letivos, mais favoráveis no segundo ano. Torna-se necessário considerar os fatores contextuais e do processo da intervenção que possam explicar tais efeitos.

Palavras-chave: adaptabilidade, intervenção psicológica, adolescência, efeitos ambientais

\section{Adaptación Escolar en el $9^{\circ}$ año: Eficacia de la intervención en dos años Escolares Consecutivos}

\begin{abstract}
Resumen: El programa Eu Pertenço ao Meu Futuro! (“¡Pertenezco a mi futuro!”) tiene evidencia de eficacia en la adaptación de los/las estudiantes portugueses/as del $9 .^{\circ}$ año. Pero todavía no se han estudiado las variaciones de esta eficacia. Este estudio pretende evaluar la eficacia de esta adaptación en dos años escolares consecutivos, 2015/16 y 2016/17, un período de cambios de gobierno con impactos en los proyectos educativos escolares. Participaron 2.376 estudiantes [1.201 (50,5\%) niños; edad $M=14,53$ años; $D E=.836], 1.138$ del grupo experimental y 816 del grupo control. Las respuestas a la Escala de Adaptabilidad, en un pre-test y posttest, con un intervalo de siete semanas, se trataron con MANOVA. Los resultados indican que la intervención logró los resultados esperados en confianza y control en el 2016/17. El programa tuvo diferentes efectos en los años escolares, más favorables en el segundo año. Es necesario considerar los factores contextuales y el proceso de intervención que pueden explicar tales efectos.
\end{abstract}

Palabras clave: adaptación, intervención psicológica, adolescencia, efectos ambientales

${ }^{1}$ Universidade do Minho, Braga, Portugal

${ }^{2}$ Universidade São Francisco, Campinas-SP, Brazil

Article derived from the master's thesis of the first author under the supervision of the second author, defended in 2020, in the Integrated Master's degree in Psychology of the School of Psychology of the Universidade do Minho.

Correspondence address: Maria do Céu Taveira. Universidade do Minho Escola de Psicologia, Campus de Gualtar, Gualtar-Braga, Portugal 4710-057. E-mail: ceuta@psi.uminho.pt
Over the past 40 years, the literature on the evaluation of vocational interventions effectiveness corroborates their positive effects (Fretz, 1981; Spokane, 2004; Spokane \& Nguyen, 2016; Whiston, Li, Mitts, \& Wright, 2017). However, several authors highlight the need for continuing with the evaluation of these interventions (Cordeiro et al., 2017; Green, Noor, \& Hashemi, 2019; Janeiro, Mota, \& Ribas, 2014), for it comprises a useful study line 
to understand the intervention and continuously adjust it to the needs of individuals (Cordeiro et al., 2017). International meta-analyses on the field indicate that vocational interventions are associated with higher levels of vocational certainty, identity, and career adaptability (Brown \& Roche, 2015; Langher, Nannini, \& Caputo, 2018; Spokane \& Nguyen, 2016; Whiston et al., 2017), and that their average effect size range from .30 to .80 , suggesting moderate to high levels of positive effects.

Moreover, vocational interventions are diverse as to theoretical model, target audience, structure, process, and evaluation method (Oliveira, Teixeira, \& Dias, 2017). Although many of the analyzed interventions employ a preand posttest, (Cardoso, Janeiro, \& Duarte, 2017; Cordeiro et al., 2017; Green et al., 2019; Maree, 2019; Santilli, Note, \& Hartung, 2018), not all of them used a control group (Cordeiro et al., 2017; Maree, 2019). Over the past ten years, career adaptability has been one of the most explored variables in these intervention (Cordeiro et al., 2017; Green et al., 2019; Maree, 2019), so that the Career Adapt-Abilities Scale-CAAS (Savickas \& Porfeli, 2012), adapted for several languages, has been the most used measure for this purpose.

Regarding study samples, most interventions targeted students from compulsory and higher education (Cardoso et al., 2017; Cordeiro et al., 2017; Green et al., 2019; Janeiro et al., 2014; Maree, 2019; Santilli et al., 2018). However, when it comes to Portuguese studies, interventions evaluation focuses on 9th-year students (Cardoso et al., 2017; Cordeiro et al., 2017; Janeiro et al., 2014). This is due to the fact that, in Portugal, the 9th school year is a transition year, at the end of which the regular curriculum ends and students must decide the type of studies to pursue in compulsory secondary education (scientific-humanistic courses, specialized artistic courses, or professional courses). To this end, most schools offer students psychological support (Mendes, Abreu-Lima, \& Almeida, 2015) and vocational intervention programs, which help them to ponder the context, process, and content of their career decisions (Lent \& Brown, 2020).

Vocational intervention has been defined as a set of strategies designed to help individuals understand themselves for making effective career decisions (Spokane, 2004). Savickas (2013) deems it crucial to promote vocational intervention strategies that allow individuals to effectively face the challenges of this new world; that is, to promote career adaptability. According to the author, this metacompetence comprises the "individual resources to deal with unfamiliar, complex and ill-defined problems inherent to current and anticipated developmental vocational tasks, occupational transitions, and personal traumas throughout life" (Savickas, 2013, pp. 15-16, our translation).

Career adaptability may be operationalized through the dimensions of concern, control, curiosity, and confidence (Savickas \& Porfeli, 2012). Concern corresponds to individuals' awareness of the need for preparing tasks of future career. Control involves taking responsibility for career development and making decisions. Curiosity refers to the willingness to explore and seek information on possible futures. Finally, confidence is characterized by the belief in personal efficacy for solving vocational tasks (Savickas \& Porfeli, 2012).

The number of transitions and the unpredictability of career trajectories have increased in recent years (Brown \& Roche, 2015). Both in the academic life and in the labor market, young people are expected to develop adaptability and assume responsibility for managing their own careers (Lent \& Brown, 2020). These challenges make adolescence a particularly important period for the design, performance, and evaluation of vocational interventions that enable such attitudes and support career transitions. In many cases, the physical and psychological changes associated with adolescence add up to career indecision (Borba \& Marin, 2018; Carvalho, 2015).

The fact that many vocational interventions target young students highlights the concern in offering early follow-up to career development (Cardoso et al., 2017; Carvalho, 2015; Cordeiro et al., 2017; Janeiro et al., 2014; Oliveira et al., 2017; Silva, 2016). Besides the positive impact, adolescents seem to value such school interventions (Carvalho, 2015). However, their implementation depends on different contextual factors, such as the government investment in the education field and in Psychology and Guidance Services (SPO) within these environments (Cordeiro et al., 2017). These interventions also occur due to the initiative and organization of schools, municipalities, and/or intermunicipal communities, within a framework of institutional or interinstitutional autonomy (Taveira, 2015), so that they also depend on this more proximal, institutional will and investment. Vocational interventions often count with the voluntary participation of students, upon enrollment and parental authorization.

According to the Decree No. 190/91 (1991), which stipulates the creation of SPOs, school psychologists should facilitate the transition of young people to the continuation of studies and the labor market, which means to say that these professionals are responsible for implementing vocational interventions within their school or in school grouping. In 2016, $59 \%$ of Portuguese schools relied on a single psychologist a low ratio of technicians per number of students (Silva, 2016). In this context, Silva (2016) states that such interventions could be more effective if the SPOs followed a general policy and gathered the most efficient technical and human resources possible. At the same time, professionals lack opportunities for specialization and training in the specialty of Vocational Psychology and Career Development (Cordeiro et al., 2017). In a study conducted by Mendes et al. (2015), $8 \%$ of the almost 500 professionals investigated identified Vocational Guidance as the intervention domain in which they required more training. For continuous education is one of the factors that most qualifies a professional, such a need should be better considered (Barros, Ambiel, \& Noronha, 2019). Moreover, school psychologists comprise a heterogeneous population, with different knowledge levels and domains, which may reflect in their professional practices (Mendes, Lasser, Abreu-Lima, \& Almeida, 2016) in terms of interventions implementation quality.

These issues may be addressed by inviting school psychologists to work in a network, creating a practical 
research community in which researchers, responsible for intermunicipal communities, municipalities, schools, and SPOs work together in mobilizing and providing resources (Barros et al., 2019; Green et al., 2019). Such cooperation will enable a mutual orientation for the design, training, implementation, and evaluation of vocational interventions aimed at students in school transition, as well as of longer preventive and promotional programs in the field (Barros et al., 2019). Practical research communities enable the implementation of intervention protocols and favor their external validity, as data collection and subsequent analysis promotes theoretical and empirically sustained interventions (Degn, Franssen, Sorensen, \& Rijcke, 2018).

In Portugal, the vocational intervention program Eu Pertenço ao Meu Futuro! (I Belong to My Future!; Taveira, 2015), was administered to several school groups in the North, Center, and South of the country. Despite its effectiveness in increasing students' career adaptability (Cordeiro et al., 2017), no analyses have been performed to evaluate whether this aspect may vary according to contextual changes such as the school year - a time cut that may be associated with certain contextual features (e.g., different groups of students, projects, and educational policies in force). Up to date, no studies have been conducted investigating whether the adaptation skills from different cohorts of adolescents would present significant differences from one school year to another while maintaining the same schools and psychologists responsible for the intervention.

The adaptability and readiness of young people at the entrance to the program may be affected by the different experiences of new students (Hirschi, 2011), time passage, eventual changes in the educational project (e.g., extended use of active teaching methods to foster students' agency and responsibility), as well as by some previous knowledge on the intervention through teachers and colleagues of the previous school year. The environmental context itself promotes a general development trend that increase students' readiness to choose a career (Hirschi, 2011). Thus, factors inherent to the environment (e.g., diversified educational offer that enables the decision-making process for providing more choices) and to the client (e.g., individual differences; readiness), as well as those related to the psychologist (e.g., training and greater competence/experience in performing the intervention model, responding to specific needs of students), may directly or indirectly affect the intervention effectiveness (Herr, 2008; Hirschi, 2011). In turn, broader contextual changes, namely political, educational, and social changes (Herr, 2008; Patton \& McIlveen, 2009), may have indirect implications in the school environment where interventions are implemented.

In Portugal, the most evident socio-educational changes of the last five years occurred after the establishment of the 21st Constitutional Government, led by so-called left-wing political forces, in November 2015. This triggered a series of changes in educational policies that were felt from 2015/16 to 2016/17 - period in which the interventions analyzed in this study took place. In 2015, the government program envisaged strengthening the competences of municipalities, in a logic of decentralization, understanding them as a fundamental structure for the management of public services in a dimension of proximity (Governo da República Portuguesa, 2015). Thus, at the end of this year, municipalities began to have greater participation in the fields of education while respecting the pedagogical autonomy of schools (Directorate General of School Administration [DGAE], 2016) - an achievement of the intermunicipal community to which this study concerns. At the beginning of 2016/17, an information note enabled school groups to hire psychologists (DGAE, 2016), which increased the number of school psychologists and strengthened their training and monitoring in terms of vocational intervention in the following years. In the same year, the Government proposed a plan to promote social equality in education and improve academic performance, granting schools more pedagogical autonomy to support experimentation projects and encourage the involvement of parents and local communities in the educational process (European Commission, 2016). With that, third-cycle students of the region in 2016/17 reached better educational outcomes than those of the previous year, i.e., lower retention and withdrawal rate (Directorate-General for Statistics of Education and Science [DGEEC], Directorate of Education Statistics Services [DSEE], \& Division of Primary and Secondary Education Statistics [DEEBS], 2018).

The positive effects of the adopted measures led the Government to promote new quality assurance systems and initiatives to enable the participation of students in policymaking and school management(European Commission, 2017), as well as to strengthen curricular flexibility according to students' needs and schools resources. Concurrently, the valuation, supply, and choice of most professionally qualifying secondary education routes progressively increased - as provided for in the Government Program (Governo da República Portuguesa, 2015). Such an educational innovation, considered a dynamic change that adds value to the processes that occur within school and translates into improvements in educational outcomes (Pedró García, 2018), facilitated the transition process in the career of students from the 9th school year, especially those with specific needs in terms of vocational development (DGEEC, DSEE, \& DEEBS, 2018).

Although the extent to which environmental factors influence personal variables is yet unknown (FernándezBallesteros, 2001), social contexts provide the conditions that shape, among others, individual self-concepts (Herr, 2008). Thus, many concerns regarding the individual career differ not only among subgroups, but also in the same individual at different points in their career development. Such concerns, information deficits, and indecisions become contents to which psychologists and clients will address. From a micro-level or direct-influence perspective, vocational intervention is a social activity that involves a psychologist and a client. In turn, at a macro level, with a more indirect influence, it refers to a sociopolitical process influenced by government policies, legislation, economics, and historical events (Herr, 2008; Super, 1990). Although understanding the characteristics of the context in which interventions take place is crucial, their effectiveness depends solely on their 
own characteristics. Regardless, as stated by Herr (2008), contextual changes that affect the behaviors and attitudes of the students may influence the program effectiveness. Before the eventuality of variations, such as student's starting point in terms of adaptability (Martinez, Baker, \& Young, 2017) and the contextual conditions in which programs are implemented (Patton \& McIlveen, 2009), repeatedly analyzing the effectiveness of vocational interventions is an added value.

This study aimed to evaluate the effectiveness of the vocational intervention program Eu Pertenço ao Meu Futuro! in two consecutive school years, 2015/16 and 2016/17 a period with a series of government changes that impacted school educational projects. We assumed that possible changes in the program effectiveness could occur from one year to another due to changes in the socio-educational context, students' attitudes and behaviors, and the mastery of psychologists responsible for the intervention. Thus, the study seeks to verify whether the program achieves the proposed goals, corroborating the results of previous investigations, and whether the pattern of results remains the same across the two school years. The following hypotheses were formulated: $\mathrm{H} 1$. We expect statistically significant differences in the intervention group (IG) between the preand posttest, with improved career adaptability in 2015/16 and in 2016/17; H2. We expect statistically significant differences between the IG and the control group (CG) regarding career adaptability in 2015/16 and 2016/17; and $\mathrm{H} 3$. We expect an association between time and group regarding career adaptability in 2015/16 and 2016/17.

\section{Method}

The Eu Pertenço ao Meu Futuro! program is an intermunicipal model of vocational intervention implemented in all public and private schools, integrated in an Intermunicipal Community, from eight municipalities in Northern Portugal. It consists of an adaptation of the Futuro Bue intervention protocol, developed at the Psychology Service of a public university in the region. The general objectives of the program include: verifying students' vocational situation (school history, aspirations, desires, goals); identifying their status in the light of decision-making; help deepening and specifying school, leisure, and professional interests; helping students to assess their competences and goals; supporting the exploration of study opportunities after the 9th year in relation to future educational and professional opportunities; and helping students to develop a plan for their decision-making and to commit to it. From a developmental approach centered on the individual (Taveira, 2015), the program is based on the modality of brief and structured psychological counseling.

The intervention consists of seven sessions conducted in small groups (six/eight students). After presenting the program to parents, pupils, and teachers, the school opens the enrolment period to students, upon parental authorization, and creates the intervention and control groups. In the first session, before presenting the program operating rules, students of the IG are invited to respond to the adaptability scale (prettest). In the same week, the school psychologist conducts a brief and structured interview with the family of enrolled students to analyze expectations regarding their career and the type of communication and joint activities performed with them related to the career, as well as to clarify doubts about the program and the decision process. This interview may be replaced by a conference with the parents of students of the same class or experimental group, in which the psychologist would dialogue with them and administer a brief questionnaire to collect data on expectations, communication, and joint activities.

Sessions with students (2-6) last 90 minutes each and intended to foster: (1) a positive vision of the future; (2) the selfexploration in relation to the occupational world and overall society; (3) the reflection on the student's role and the factors involved in the career decision-making process; (4) the definition of short- and medium-term career goals; (5) the creation and evaluation of alternatives; and (6) the anticipation of barriers and support to their accomplishment. The posttest is administered in the last session, and a new interview is conducted with each student and their respective families to reassess and show the support process and necessary steps for the successful execution of the career plan designed in the intervention. Intervention activities include drafting a contribution agreement; performing exercises and guided-discussions about career review, interests, and aspirations; designing an action plan (session 2); deepening occupational interests and values; exploring inventoried interests with feedback; designing the life career rainbow; (re)evaluating the action plan (session 3); performing a guided decision-making exercise with diagnosis of alternatives, broad and in-depth exploration, and commitment to an action plan (sessions 4 and 5).

\section{Participants}

The study was conducted with a convenience sample of 2376 students from two municipalities of an intermunicipal community in Northern Portugal, in 2015/16 and 2016/17. Of these, $1201(50.5 \%)$ were boys and 1163 (48.9\%) girls, aged between 12 and 18 years. $(M=14.53, S D=.836)$. The 2015/16, sample consisted of 1,236 students ( $I G=693$ and $C G=543), 533$ of whom were from one municipality and 901 from the other. In turn, the 2016/17 sample included 718 students $(\mathrm{IG}=445$ and $\mathrm{CG}=273), 636$ from the first municipality and 57 from the other.

\section{Instruments}

Adaptability Scale (Duarte et al., 2012): the Portuguese adaptation of the Career Adapt-Abilities Scale - CAAS (Savickas \& Porfeli, 2012), an instrument used to assess adaptability. The Portuguese version of CAAS includes 28 items divided into four dimensions, resulting in one extra item per dimension when compared to the original version, answered according to a five-point Likert scale (1 - Never to 5 Very frequently), namely: concern (e.g., item 4 "Preparing for 
the future"); control (e.g., item 12 "Count on myself"); curiosity (e.g., item 15 "Exploring what surrounds me"); and confidence (e.g., item 26 "Overcoming obstacles"). The instrument shows high reliability, with Cronbach's alpha of .90 , and results of .76 for concern, .69 for control, .78 for curiosity, and .79 for confidence (Duarte et al., 2012). In this study, the scale reliability coefficients for 2015/16 and 2016/17, respectively, were .82 in the two years for control; .80 and .81 for concern; .84 and .75 for curiosity; and .87 and .82 for confidence.

\section{Procedure}

Data collection. Data were collected under the protocol established between the university responsible for the study and the Intermunicipal Community. Participants consisted of nearly all 9th-year students from each group who had enrolled for vocational intervention at their school. School administration and those in charge of education granted authorization for the study, ensuring the voluntary participation of young people. The research included a pretest, the Eu Pertenço ao Meu Futuro! program implementation, and a posttest. Data were treated by specialists, and confidentiality was ensured by means of an informed consent. Assessments were performed with a seven-week interval, in the two school years. The investigation followed a quasi-experimental design, including a pre- and posttest and randomizing the study sample into IG and CG (without the intervention). Students of the CG participated later in the intervention. Each school had a psychologist responsible for the project who was trained in the program model and accompanied through regular, bimonthly meetings.

Data analysis. Statistical analyses were performed using IMB Statistical Package for the Social Sciences (SPSS) 26.0 for Windows. Data were processed, analyzing missing values and creating variables. To characterize the sample and the dimensions of adaptability in the pre- and posttest, a descriptive analysis (mean, minimum/maximum value, and standard deviation) was conducted for each year. The effect of time, group, and time-group interaction on the career adaptability dimensions were evaluated by testing the assumptions for the performance of two two-way multivariate analysis of variance (MANOVA), indicating compliance with the assumptions of scouting and independence, normality, number of cases per cell, and absence of singularity and multicolinearity in the two evaluated years. For 2015/16, all dimensions showed homogeneity of variance matrices, except for concern $(p=.003)$ and curiosity $(\mathrm{p}=.049)$ in the posttest. As for 2016/17, all adaptability dimensions met the assumption. However, the homogeneity of covariance matrices was violated in both years. The vocational intervention effect size was calculated using Cohen's d corrected by the Hedges-Olkin method (1985) and interpreted as follows: lower than .20 (small), up to .50 (medium), .50 to .80 (large), and above .80 (elevated) (Cohen, 1988, p. 82).

\section{Ethical Considerations}

Being conducted after data collection and prior to the 2019 RT-31 Order, which established the creation of the Portuguese Ethics Committee, this research was not submitted to an Ethics Committee. Instead, data collection was authorized by the Intermunicipal Community in which the research was conducted and the competent authorities of schools participating in the program, under the Protocol involving the University and the intermunicipal entity responsible for the school psychologists' network (September, 2015 - valid for five years). Data collection and methodological procedures followed the principles of research ethics outlined in the Social and Human Sciences Section of the University Ethics Committee. The students were informed about the research objectives and, after signing the informed consent form, responded to the instrument.

\section{Results}

Table 1 shows the descriptive analyses of the adaptability dimensions, the MANOVA results, and the effect size for each school year.

Table 1

Career adaptability: intragroup and intergroup differences

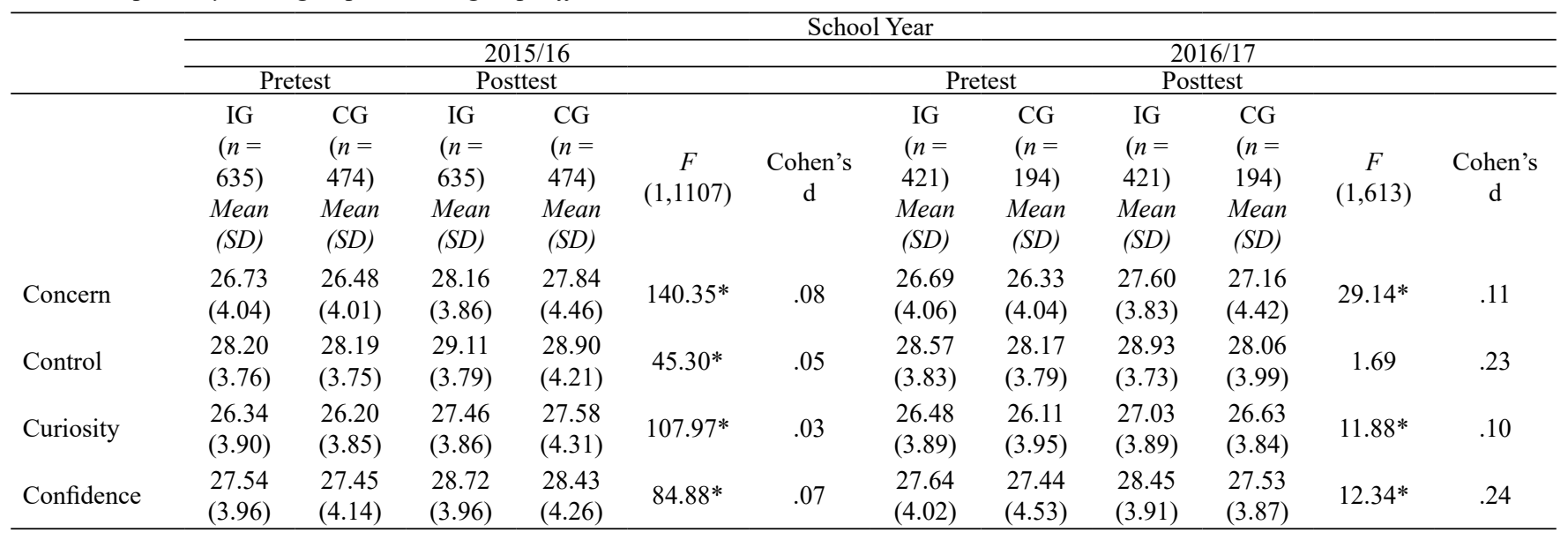

Note. ${ }^{*} p<.05$. 
For 2015/16, descriptive analyses indicate that the subscales with highest mean in the pretest were control and confidence, both in the IG and in the CG. The posttest showed the same pattern of descriptive results. The differential analyses showed that the adaptability conditions of all participants prior to the intervention were similar and positive. Moreover, the MANOVA results suggest a statistically significant multivariate effect of time in all dimensions, with Wilks' Lambda $=.871$, $F(4,1104)=41,033$, and $p=.000$. Regarding univariate analysis, time shows a significant effect in all adaptability dimensions, with concern $F(1,1107)=140.35, p=.000$; control $F(1,1107)=45.30, p=.000$; curiosity $F(1,1107)=107.97$, $p=.000$, and confidence $F(1,1107)=84.88, p=.000$. We found no statistically significant multivariate or univariate differences between the groups.

As for 2016/17, descriptive analyses indicate that the subscales with highest mean in the pre- and posttest in both groups were control and confidence. Like in the first studied period, differential analyses showed that the adaptability conditions of all participants prior to the intervention were similar and positive. The MANOVA results reveal a statistically significant multivariate effect of time, with Wilks' Lambda $=.941, F(4,610)=9,620, p=.000$. In terms of univariate effects, we obtained statistically significant results in the concern $F(1,613)=29.14, p=.000$; curiosity $F(1,613)=11.88, p=.010$; and confidence subscales $F(1,613)=12.34, p=.000$. The groups showed no statistically significant multivariate or univariate differences, but the univariate analysis verified significant differences in the control subscale $F(1,613)=5.09, p=.024$, to the disadvantage of the $\mathrm{CG}$. We found no significant multivariate differences as for the effects of time interaction with the group, but the univariate analysis shows significant differences in the confidence subscale $F(1,613)=4.18$, $p=.041$, in favor of the IG. As for effect size, the control $(d=.23)$ and confidence $(d=.24)$ subscales show medium effect whereas concern $(d=.10)$ and curiosity $(\mathrm{d}=.11)$ show low effect.

\section{Discussion}

This study sought to contribute to the literature on the evaluation of vocational interventions effectiveness in the career adaptability of adolescents (Cordeiro et al., 2017; Green et al., 2019; Janeiro et al., 2014; Obi, 2015). It also ponders the implications for the application and development of such interventions, investigating their effectiveness in two consecutive school years - 2015/16 and 2016/17. For 2015/16, our results corroborate the first hypothesis, with statistically significant differences between the preand posttest in the four adaptability dimensions, as found in other studies with the same intervention model (Cordeiro et al., 2017). Although the IG reached higher values than the $\mathrm{CG}$ in all dimensions, we verified no statistically significant differences between them, thus rejecting the second study hypothesis. Our third hypothesis, regarding the effects of time-group interaction, was not confirmed. Despite the absence of differences between IG and CG, these results seem to indicate that the intervention had positive effects; however, it does not allow to conclude its effectiveness on a perennial basis. Our results indicate that the intervention could have been more intensified and incisive regarding the use of critical elements of the model that ensure its effectiveness, such as feedback and support in interpreting interests assessment and the use of valid information on educational opportunities (Spokane \& Nguyen, 2016). Moreover, these results may be explained by a possible interaction between students of the IG and CG throughout the process, thus contaminating the experience of students of the $\mathrm{CG}$, who improved their adaptability without intervention. Our findings reinforce the urgent need for promoting educational intervention programs with the intentional participation of adolescents (Carvalho, 2015; Cordeiro et al., 2017; Janeiro et al., 2014).

Regarding 2016/17, the first hypothesis was partially confirmed, with students perceiving themselves as more adaptable in terms of concern, curiosity, and confidence in the posttest. This means that students were more aware of the need to plan their careers, more curious and open to seek information about study and professional opportunities, and more confident in solving these tasks (Savickas \& Porfeli, 2012). The second hypothesis was likewise partially confirmed, as students of the IG showed better results than those of the CG, suggesting that students who participated in the program feel more responsible and proactive in terms of decision-making (Savickas \& Porfeli, 2012). The third hypothesis was partially accepted, as students of the IG felt more confident in the posttest than those of the CG. Our results indicate that the program has improved how students perceive their efficiency, showing they can do their best in performing tasks, that they are able to acquire new skills, and that they can overcome obstacles, solve problems, and face new challenges (Duarte et al., 2012). Students who participated in the program believe they have ease in maintaining their spirits while making decisions based on their convictions, taking responsibility for their actions (Duarte et al., 2012). Such an increase in positive beliefs and career responsibility is a key element to the decision imposed on 9th-year students, indicating that the program has achieved its primary purpose - as confirmed by the medium effect recorded for confidence (.24) and control (.23) (Janeiro et al., 2014; Langher et al., 2018; Maree, 2019).

Being the result of a dynamic person-context interaction (Hirschi, 2009), the patterns of career development entail considerable plasticity and variability, especially in adolescence (Hirschi, 2011). Thus, after analyzing the program impact on the adaptability of participants, we may formulate hypotheses about the results considering the changes in the intervention context and their possible effects on the work of psychologists, on the readiness and availability of students, and in school educational projects. Regarding psychologists, we should consider the increased number of school psychologists in 2016/17 (DGAE, 2016) due to the greater hiring autonomy granted to school groups (DGAE, 2016), which enabled the intervention to be more 
focused on students' needs (Mendes et al., 2016; Silva, 2016). Moreover, the psychologists responsible for implementing the program had one year of experience in 2016/17, and training is essential for a psychologist to specialize in a given task (Barros et al., 2019; Cordeiro et al., 2017). At the end of the 2015/16 program implementation, a consulting was offered to school psychologists in the context of networking and research-informed practice (Barros et al., 2019; Degn et al., 2018; Green et al., 2019). Besides promoting professional development, autonomy, and the quality of the services provided, this post-intervention work also sought to standardize the experimental procedures adopted by professionals and to raise awareness of the relevance of their participation in the research (e.g., data collection and evaluation).

Regarding students' readiness, in addition to the aforementioned variability of individual adaptability, one should also consider the following contextual factors (Herr, 2008; Hirschi, 2011): an attempt to strengthen social equality on the part of the Government; the best educational outcomes in 2016/17 when compared to the previous year; the greater curricular flexibility and pedagogical autonomy in 2016/17; the proximity of 2016/17 participants to participants from the past year; and the overall trend of individual development (Hirschi, 2011). These conditions may shape individual self-concepts (Herr, 2008), thus favorably affecting the predisposition (Pedró García, 2018) and the starting point of students in terms of adaptability (Martinez et al., 2017). Finally, educational projects reflect broader contextual changes of political, educational, and social nature (Herr, 2008; Patton \& McIlveen, 2009), including all of the most proximal changes mentioned above. Although the identified contextual differences do not justify the distinct effects of the program in the two consecutive school years, they highlight both the need for considering contextual factors and the intervention process that may explain such effects.

Among the limitations to the generalization and validity of the results, we may stress the use of a convenience sample and the obstacles in applying the program in the north of the country; the apparent contamination between the IG and the CG; the lack of a follow-up session; and the exclusive use of quantitative methods. Thus, we suggest further research to implement and evaluate the program in the rest of the country, ensuring that students of the IG and GC do not contact each other (e.g., belong to different schools/classes), including follow-up sessions and feedbacks (Green et al., 2019; Janeiro et al., 2014; Obi, 2015), and using mixed methods (quantitative and qualitative measures) in adaptability assessment (e.g., consider the opinion of psychologists) (Cardoso et al., 2017; Green et al., 2019). Moreover, to understand how and to which extent environmental factors influence personal variables (Fernández-Ballesteros, 2001), future investigations could evaluate differences in the educational project, in the ratio/training/specialization of school psychologists, in the program implementation mode, and in individual variables of the students.
The program Eu Pertenço Ao Meu Futuro! has effects on the career adaptability of adolescents, justifying the need for investment so that it continues to be implemented in Portuguese schools. The factors inherent to the environment and to the intervention process here mentioned should be deemed as facilitating factors in a context conducive to intervention. The research described in this article relied on the participation of thousands of students and on the dedication and commitment of hundreds of psychologists, thus providing a set of practical implications, such as: the importance of collaboration between psychologists and academics (Barros et al., 2019; Green et al., 2019); the relevance of educational and political decision-makers in school education projects; the added value of partnerships between scientific associations and school institutions and municipalities or intermunicipal communities in achieving career interventions (Barros et al., 2019); and the need for increasing the ratio of psychologists per student in Portuguese schools (Mendes et al., 2016).

\section{References}

Barros, L. O., Ambiel, R. A. M., \& Noronha, A. P. P. (2019). Indicadores de formação teórica e prática de orientadores profissionais e de carreira [Indicators of theoretical and practical training of vocational guidance practitioners]. Revista Brasileira de Orientação Profissional, 20(2), 107-118. doi:10.26707/19847270/2019v20n2p107

Borba, B. M.R., \& Marin,A.H.(2018). Indicators of emotional and behavioral problems in adolescents: Evaluation among multiple informants. Paidéia (RibeirãoPreto), 28, e2825. doi:10.1590/1982-4327e2825

Brown, S. D., \& Roche, M. (2015). The outcomes of vocational interventions: Thirty (some) years later. Journal of Career Assessment, 24(1), 26-41. doi:10.1177/1069072715579666

Cardoso, P., Janeiro, I. N., \& Duarte, M. E. (2017). Life design counseling group intervention with Portuguese adolescents: A process and outcome study. Journal of Career Development, 45(2), 183196. doi: $10.1177 / 0894845316687668$

Carvalho, R. G. (2015). Quantitative and qualitative assessment of adolescents' future time perspective. Paidéia (Ribeirão Preto), 25(61), 163-172. doi:10.1590/1982-43272561201504

Cohen, J. E. (1988). The significance of a Product Moment rs. In Statistical power analysis for the behavioral sciences (pp. 75-108). New York, NY: Lawrence Erlbaum.

ComissãoEuropeia.(2016).MonitordaEducaçãoedaFormação 2016: Portugal [Education and Training Monitor 2016: Portugal]. Retrieved from https://www.cnedu.pt/ https://www.cnedu.pt/content/noticias/internacional/ monitor2016-pt_pt.pdf 
Comissão Europeia. (2017). Monitor da Educação e da Formação 2017: Portugal [Education and Training Monitor 2017: Portugal]. Retrieved from https://www.cnedu.pt/ https://www.poch.portugal2020.pt/pt-pt/Candidaturas/ Documents/monitor2017-pt_pt.pdf

Cordeiro, S. A., Taveira, M. C., Neves, L., Silva, A. D., Rodrigues, B., \& Costa-Lobo, C. (2017). Efeitos de uma intervenção psicológica vocacional na adaptabilidade de carreira [Effects of a vocational psychological intervention on career adaptability]. Revista de Psicologia da Criança e do Adolescente, 8, 93-104. Retrieved from http://revistas. lis.ulusiada.pt/index.php/rpca/article/view/2480/pdf

Decreto-Lei No. 190 (1991, 17 de maio). Cria nos estabelecimentos de educação e ensino públicos os serviços de psicologia e orientação. Diário da República, série 1-A. Recuperado de https://data.dre.pt/eli/dec-lei/ 190/1991/05/17/p/dre/pt/html

Degn, L., Franssen, T., Sorensen, M. P., \& Rijcke, S. (2018). Research groups as communities of practice - A case study of high-performing research groups. Higher Eucation, 76(2), 231-246. doi:10.1007/s10734-017-0205-2

Direção Geral da Administração Escolar. (2016). Nota Informativa: Necessidades temporárias de formação em areas técnicas especificas - Contratação de psicólogos [Informative Note: Temporary training needs in specific technical areas - Hiring psychologists]. Retrieved from https://www.dgae.mec.pt/download/ recrutamento/notas_informativas/201617/20160901_ rec_ni_ContatacaoEsc_Psicologos.pdf

Direção-Geral de Estatísticas da Educação e Ciência, Direção de Serviços de Estatísticas da Educação, \& Divisão de Estatísticas do Ensino Básico e Secundário. (2018). Regiões em números 2016/2017 - Norte [Regions in numbers 2016/2017 - North] (Vol. 1). Retrieved from https://www.dgeec.mec.pt/np4/96/

Duarte, M. E., Soares, M. C., Fraga, S., Rafael, M., Lima, M. R., Paredes, I., ... Djaló, A. (2012). Career Adapt-Abilities Scale-Portugal form: Psychometric properties and relationships to employment status. Journal of Vocational Behavior, 80(3), 725-729. doi:10.1016/j.jvb.2012.01.019

Fernández-Ballesteros, R. (2001). Environmental conditions, health and satisfaction among the elderly: Some empirical results. Psicothema, 13(1), 41-49.

Fretz, B. R. (1981). Evaluating the effectiveness of career interventions. Journal of Counseling Psychology, 28(1), 77-90. doi:10.1037/0022-0167.28.1.77

Governo da República Portuguesa. (2015). Programa do XXI Governo Constitucional 2015-2019 [XXI Constitutional Government Program 2015-2019]. Retrieved from https://www.portugal.gov.pt/ficheirosgeral/programa-do-governo-pdf.aspx

Green, Z. A., Noor, U., \& Hashemi, M. N. (2019). Furthering proactivity and career adaptability among university students: Test of intervention. Journal of Career Assessment, 28(3), 402-424. doi:10.1177/1069072719870739
Hedges, L. V., \& Olkin, I. (1985). Statistical methods for meta-analysis. San Diego, CA: Academic Press.

Herr, E. L. (2008). Social contexts for career guidance throughout the world. In J.A. Athanasou \& R. Van Esbroeck (Eds.), International handbook of career guidance (pp. 45-67). Dordrecht, The Netherlands: Springer.

Hirschi, A. (2009). Swiss adolescents' career aspirations: Influence of context, age, and career adaptability. Journal of Career Development, 36(3), 228-245. doi:10.1177/0894845309345844

Hirschi, A. (2011). Career-choice readiness in adolescence: Developmental trajectories and individual differences. Journal of Vocational Behavior, 79(2), 340-348. doi:10.1016/j.jvb.2011.05.005

Janeiro, I. N., Mota, L. P., \& Ribas, A. M. (2014). Effects of two types of career interventions on students with different career coping styles. Journal of Vocational Behavior, 85(1), 115-124. doi:10.1016/j.jvb.2014.05.006

Langher, V., Nannini, V., \& Caputo, A. (2018). What do university or graduate students need to make the cut? A meta-analysis on career intervention effectiveness. Journal of Educational, Cultural and Psychological Studies, 17, 21-43. doi:10.7358/ecps-2018-017-lang

Lent, R. W., \& Brown, S. D. (2020). Career decision making, fast and slow: Toward an integrative model of intervention for sustainable career choice. Journal of Vocational Behaviour, 120, 103448. doi:10.1016/j.jvb.2020.103448

Maree, J. G. (2019). Group career construction counseling: A mixed-methods intervention study with high school students. The Career Development Quarterly, 67(1), 4761. doi:10.1002/cdq. 12162

Martinez, R. R., Baker, S. B., \& Young, T. (2017). Promoting career and college readiness, aspirations, and selfefficacy: Curriculum field test. The Career Development Quarterly, 65(2), 173-188. doi:10.1002/cdq.12090

Mendes, S. A., Abreu-Lima, I., \& Almeida, L. S. (2015). Psicólogos escolares em Portugal: Perfil e necessidades de formação [School psychologists in Portugal: Training profile and educational needs]. Estudos de Psicologia (Campinas), 32(3), 405-416. doi:10.1590/0103-166X2015000300006

Mendes, S. A., Lasser, J., Abreu-Lima, I., \& Almeida, L. S. (2016). All different or all the same? Exploring the diversity of professional practices in Portuguese school psychology. European Journal of Psychology of Education, 32(2), 251-269. doi:10.1007/s10212-016-0297-6

Obi, O. P. (2015). Constructionist career counseling of undergraduate students: An experimental evaluation. Journal of Vocational Behavior, 88, 215-219. doi:10.1016/j.jvb.2015.03.009

Oliveira, C. T., Teixeira, M. A. P., \& Dias, A. C. G. (2017). Revisão sistemática da literatura sobre características de intervenções em carreira [Systematic literature review on characteristics of career interventions]. Revista de Psicologia da IMED, 9(2), 125-141. doi:10.18256/ 2175-5027.2017.v9i2.1464 
Patton, W. A., \& Mcllveen, P. F. (2009). Context and models for the analysis of individual and group needs. The Career Development Quarterly, 57(4), 327-334. doi:10.1002/j.2161-0045.2009.tb00118.x

Pedró García, F. (2018). Tendencias internacionales en innovación educativa: Retos y oportunidades [Intentional trends in educational innovation: Challenges and opportunities]. In F. Rey \& M. Jabonero (Coords.), Sistemas educativos decentes (pp. 71-99). Madrid, España: Fundación Santillana/Junta de Castilla y León.

Santilli, S., Nota, L., \& Hartung, P. J. (2018). Efficacy of a group career construction intervention with early adolescent youth. Journal of Vocational Behavior, 111, 49-58. doi:10.1016/j.jvb.2018.06.007

Savickas, M. L. (2013). Career construction theory and practice. In S. D. Brown \& R. W. Lent (Eds.), Career development and counseling: Putting theory and research to work (2nd ed., pp. 147-183). Hoboken, NJ: John Wiley \& Sons.

Savickas, M. L., \& Porfeli, E. J. (2012). Career AdaptAbilities Scale: Construction, reliability, and measurement equivalence across 13 countries. Journal of Vocational Behavior, 80(3), 661-673. doi:10.1016/j. jvb.2012.01.011

Silva, L. (2016). Estudo sobre a orientação vocacional e profissional: Escolhas [Study on Vocational Guidance and Professional: Choices]. Psicologia Escolar e Educacional, 20(2), 239-244. doi:10.1590/21753539/2015/0202957

Spokane, A. (2004). Avaliação das intervenções de carreira [Evaluation of career interventions]. In L. Leitão (Coord.), Avaliação psicológica em orientação escolar e profissional (pp. 455-473). Coimbra, Portugal: Quarteto.

Spokane, A. R., \& Nguyen, D. (2016). Progress and prospects in the evaluation of career assistance. Journal of Career Assessment, 24(1),3-25. doi:10.1177/1069072715579665

Super, D. (1990). A life-span, life-space approach to career development. In D. Brown \& L. Brooks (Eds.), Career choice and development: Applying contemporary theories to practice (2nd ed., pp. 197-261). San Francisco, CA: Jossey Bass.

Taveira, M. C. (2015). Eu pertenço ao Meu Futuro! Programa de Intervenção Vocacional: Versão para os alunos do 9. ${ }^{\circ}$ ano de escolaridade 2015-2016 [“I belong to My Future!" Vocational Intervention Program: Version for students of the 9th grade 2015-2016]. Vila Nova de Famalicão, Portugal: Rede Local de Educação e Formação de Vila Nova de Famalicão.

Whiston, S. C., Li, Y., Mitts, N. G., \& Wright, L. (2017). Effectiveness of career choice interventions: A metaanalytic replication and extension. Journal of Vocational Behavior, 100, 175-184. doi:10.1016/j.jvb.2017.03.010
Catarina Luzia de Carvalho is a Research Fellow and a $\mathrm{Ph}$.D. candidate of the $\mathrm{PhD}$ in Applied Psychology Program at the Universidade do Minho, Braga, Portugal.

Maria do Céu Taveira Cunha is a Professor at the Universidade do Minho, Braga, Portugal.

Rodolfo Augusto Matteo Ambiel is a Professor at the Universidade São Francisco, Campinas-SP, Brazil.

\section{Authors' Contribution:}

All authors made substantial contributions to the conception and design of this study, to data analysis and interpretation, and to the manuscript revision and approval of the final version. All authors assume public responsibility for the content of the manuscript.

Associate Editor:

Eduardo Name Risk

Received: Mar. 09, 2021

1st Revision: May. 22, 2021

2nd Revision: Jun. 22, 2021

Approved: Jun. 24, 2021
How to cite this article:

Carvalho, C. L., Taveira, M. C., \& Ambiel, R. A. M. (2021). Career adaptability in the 9th year: Efficacy of an intervention in two consecutive school years. Paidéia (Ribeirão Preto), 31, e3132.doi:https://doi.org/10.1590/1982-4327e33132 